Probabilistic Mean Quantitative Structure-Property Relationship modelling of Jet Fuels Properties Clemens Hall ${ }^{1, *}$, Benoit Creton ${ }^{2}$, Bastian Rauch ${ }^{1}$, Uwe Bauder ${ }^{1}$, Manfred Aigner ${ }^{1}$ ${ }^{1}$ DLR, German Aerospace Center, Institute of Combustion Technology, MAT, 70569 Stuttgart, Germany.

${ }^{2}$ IFP Energies nouvelles, 1 et 4 avenue de Bois-Préau, 92852 Rueil-Malmaison, France.

Table S1 Comparison of modelling methods for jet fuel property prediction

\begin{tabular}{|l|l|l|l|}
\hline & $\begin{array}{l}\text { Direct GCxGC } \\
\text { correlation }\end{array}$ & $\begin{array}{l}\text { QSPR model with } \\
\text { mixing rules }\end{array}$ & M-QSPR model \\
\hline $\begin{array}{l}\text { Available training } \\
\text { data }\end{array}$ & Fuel data & Pure compound data & $\begin{array}{l}\text { Pure compound data } \\
\text { \& fuel data }\end{array}$ \\
\hline $\begin{array}{l}\text { Flexibility and } \\
\text { extensibility to } \\
\text { model new fuel } \\
\text { composition }\end{array}$ & Lower & Higher & Higher \\
\hline $\begin{array}{l}\text { Necessity of mixing } \\
\text { rule }\end{array}$ & No & Yes & No \\
\hline
\end{tabular}


Table S2 Considered molecular families for GCxGC measurements and classification criteria

\begin{tabular}{|c|c|c|c|}
\hline Family & Formula & Structural criteria & Example \\
\hline N-alkanes & $\mathrm{C}_{n} \mathrm{H}_{2 n+2}$ & $\begin{array}{l}\text { No atoms in rings } \\
\text { No branched carbon } \\
\text { bonds }\end{array}$ & \\
\hline Iso-alkanes & $\mathrm{C}_{n} \mathrm{H}_{2 \mathrm{n}+2}$ & $\begin{array}{l}\text { - No atoms in rings } \\
\text { - At least one branched } \\
\text { carbon bond }\end{array}$ & \\
\hline Mono-cyclo-alkanes & $\mathrm{C}_{\mathrm{n}} \mathrm{H}_{2 \mathrm{n}}$ & $\begin{array}{l}\text { - One aliphatic ring } \\
\text { - No aromatic rings }\end{array}$ & \\
\hline Bi-cyclo-alkanes & $\mathrm{C}_{n} \mathrm{H}_{2 n-2}$ & $\begin{array}{l}\text { - Two aliphatic rings } \\
\text { - No aromatic rings }\end{array}$ & \\
\hline Mono-aromatics & $\mathrm{C}_{\mathrm{n}} \mathrm{H}_{2 \mathrm{n}-6}$ & $\begin{array}{l}\text { - No aliphatic rings } \\
\text { - One aromatic ring }\end{array}$ & \\
\hline Cyclo-aromatics & $\mathrm{C}_{n} \mathrm{H}_{2 n-8}$ & $\begin{array}{l}\text { - One aliphatic ring } \\
\text { - One aromatic ring }\end{array}$ & \\
\hline Di-aromatics & $\mathrm{C}_{\mathrm{n}} \mathrm{H}_{2 \mathrm{n}-12}$ & $\begin{array}{l}\text { - No aliphatic rings } \\
\text { - Two aromatic rings }\end{array}$ & \\
\hline
\end{tabular}


Table S3 Percental comparison of integrated area difference of the chemical space and application domain of molecules generated by MOLGEN and utilized pure compound database for considered hydrocarbon families with 12 carbon atoms. Calculated by summing the relative differences for every hydrocarbon family between the area of pure compound database and the molecules generated by MOLGEN for each feature for.

\begin{tabular}{|l|l|l|l|l|l|l|}
\hline n-alkanes & iso-alkanes & $\begin{array}{l}\text { mono-cyclo- } \\
\text { alkanes }\end{array}$ & $\begin{array}{l}\text { bi-cyclo- } \\
\text { alkanes }\end{array}$ & $\begin{array}{l}\text { cyclo- } \\
\text { aromatics }\end{array}$ & $\begin{array}{l}\text { mono- } \\
\text { aromatics }\end{array}$ & $\begin{array}{l}\text { di- } \\
\text { aromatics }\end{array}$ \\
\hline $100 \%$ & $97.15 \%$ & $84.97 \%$ & $48.88 \%$ & $65.01 \%$ & $100 \%$ & $25.77 \%$ \\
\hline
\end{tabular}


Figure S4 Comparison of the chemical spaces and application domain of molecules generated by MOLGEN and the utilized pure compound database for cyclo-aromatics with 12 carbon atoms.

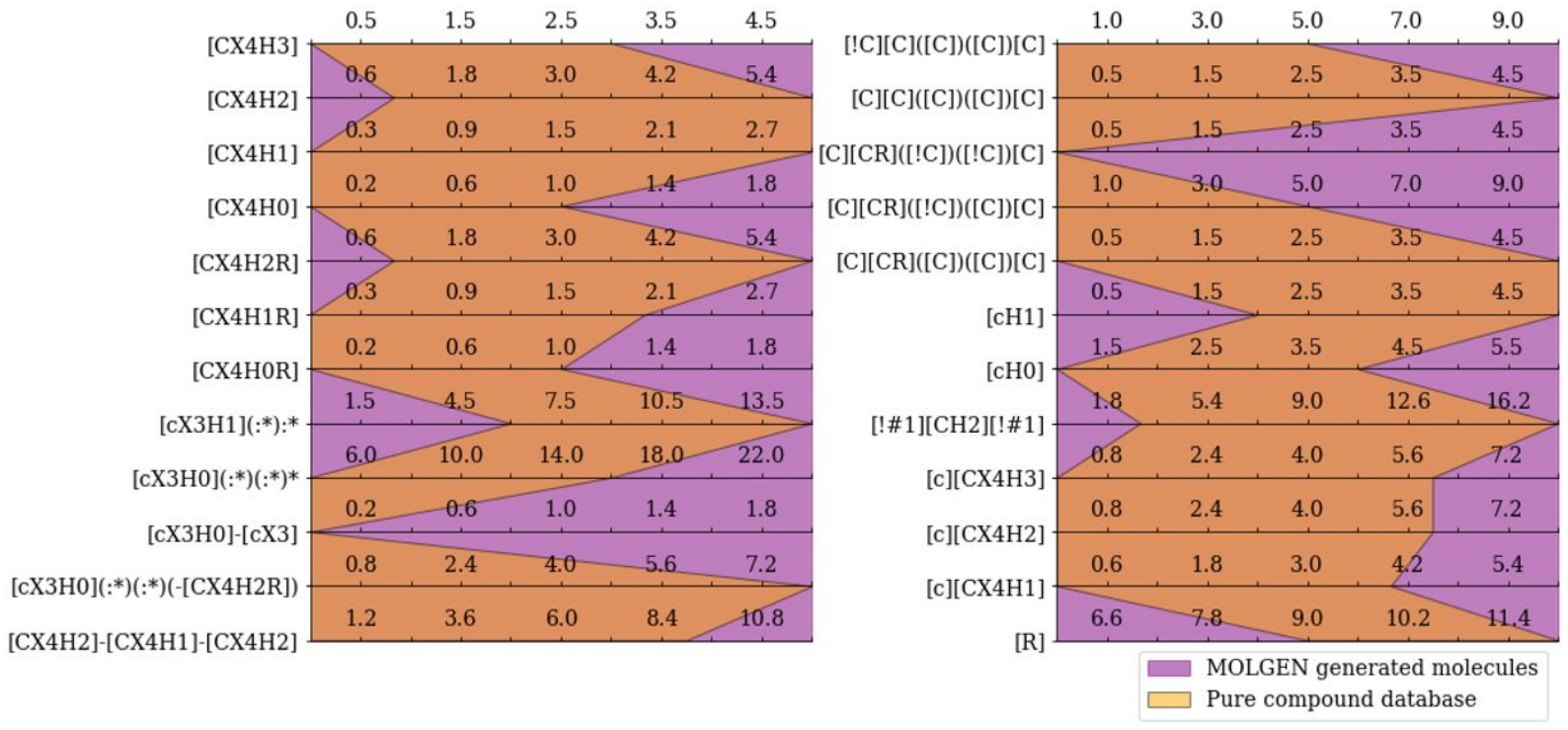


Table S5 Description of utilized structural molecular features

\begin{tabular}{|c|c|}
\hline Feature & Description \\
\hline [CX4H3] & Aliphatic $\mathrm{C}$ with 1 further total connection with 3 further hydrogen \\
\hline [CX4H2] & Aliphatic $\mathrm{C}$ with 2 further total connections with 2 further hydrogen \\
\hline [CX4H1] & Aliphatic $C$ with 3 further total connections with 1 further hydrogen \\
\hline [CX4HO] & Aliphatic $\mathrm{C}$ with 4 further total connections with 0 further hydrogen \\
\hline [CX4H1] & Aliphatic $\mathrm{C}$ with 1 further total connection with 2 further hydrogen \\
\hline [CX3H1] & Aliphatic $\mathrm{C}$ with 2 further total connections with 1 further hydrogen \\
\hline [CX3HO] & Aliphatic $\mathrm{C}$ with 3 further total connections with 0 further hydrogen \\
\hline [CX2H1] & Aliphatic $\mathrm{C}$ with 1 further total connection with 1 further hydrogen \\
\hline [CX2H0] & Aliphatic $\mathrm{C}$ with 2 further total connections with 0 further hydrogen \\
\hline$[\mathrm{CX} 4 \mathrm{H} 2 \mathrm{R}]$ & Aliphatic $\mathrm{C}$ with 2 further total connections 2 further hydrogen, in a ring \\
\hline [CX4H1R] & Aliphatic $\mathrm{C}$ with 3 further total connections 1 further hydrogen, in a ring \\
\hline [CX4HOR] & Aliphatic $\mathrm{C}$ with 4 further total connections 0 further hydrogen, in a ring \\
\hline$[\mathrm{CX} 3 \mathrm{H} 1 \mathrm{R}]$ & Aliphatic $\mathrm{C}$ with 2 further total connections 1 further hydrogen, in a ring \\
\hline$[\mathrm{CX} 3 \mathrm{HOR}]$ & Aliphatic $\mathrm{C}$ with 3 further total connections 0 further hydrogen, in a ring \\
\hline [cX3H1](:*):* & Aromatic $\mathrm{C}$ with 0 further total connections with 1 further hydrogen \\
\hline$[\mathrm{cX} 3 \mathrm{HO}]\left(:^{*}\right)\left(:^{*}\right)^{*}$ & Aromatic $\mathrm{C}$ with 0 further total connections with 0 further hydrogen \\
\hline$[\mathrm{cX} 3 \mathrm{HO} 0]\left(:^{*}\right)\left(:^{*}\right): *$ & Aromatic $\mathrm{C}$ with 0 further total connections with 0 further hydrogen \\
\hline$[\mathrm{cX} 3 \mathrm{HO}]-[\mathrm{cX} 3]$ & Aromatic $\mathrm{C}$ with 2 further total connections with 0 further hydrogen \\
\hline$[\mathrm{cX} 3 \mathrm{HO}]\left(:^{*}\right)\left(:^{*}\right)\left(:^{*}\right)$ & Aromatic $\mathrm{C}$ with 0 further total connections with 0 further hydrogen \\
\hline$[\mathrm{cX} 3 \mathrm{HO}]\left(:^{*}\right)\left(:^{*}\right)(-[\mathrm{CX} 4 \mathrm{H} 2 \mathrm{R}])$ & $\begin{array}{l}\text { Aromatic } \mathrm{C} \text { with } 0 \text { further total connections with } 0 \text { further hydrogen with } \\
\text { connection to an aliphatic } \mathrm{C} \text { with } 1 \text { further total connection with } 2 \text { further } \\
\text { hydrogen, in a ring }\end{array}$ \\
\hline [CX4H2]-[CX4H1]-[CX4H2] & Bound of aliphatic $\mathrm{C}$ with 1 further total connection with 1 further hydrogen \\
\hline$[C][C]([! C X 1])([! C X 1])[! C X 1]$ & $\begin{array}{l}\text { Bound of aliphatic } \mathrm{C} \text { with one further aliphatic } \mathrm{C} \text { and } 3 \text { non } \mathrm{C} \text { atoms with } 0 \\
\text { further total connections }\end{array}$ \\
\hline$[! C][C]([C])([C])[C]$ & Bound of aliphatic $\mathrm{C}$ with two 3 further aliphatic $\mathrm{C}$ and one non $\mathrm{C}$ atom \\
\hline$[C][C]([C])([C])[C]$ & Bound of aliphatic $\mathrm{C}$ with 4 further aliphatic $\mathrm{C}$ \\
\hline$[C][C R]([! C])([! C])[C]$ & $\begin{array}{l}\text { Bound of aliphatic } \mathrm{C} \text { in a ring with two further aliphatic } \mathrm{C} \text { and two non } \mathrm{C} \\
\text { atoms }\end{array}$ \\
\hline$[C][C R]([! C])([C])[C]$ & $\begin{array}{l}\text { Bound of aliphatic } \mathrm{C} \text { in a ring with three further aliphatic } \mathrm{C} \text { and one non } \mathrm{C} \\
\text { atoms }\end{array}$ \\
\hline$[C][C R]([C])([C])[C]$ & Aliphatic $C$ in a ring with 4 further aliphatic $C$ \\
\hline
\end{tabular}




\begin{tabular}{|c|c|}
\hline [cH1] & Aromatic $\mathrm{C}$ with 1 further connection \\
\hline [cHO] & Aromatic $\mathrm{C}$ with $\mathrm{O}$ further connections \\
\hline$[C]=[C]([! C X 1])[! C X 1]$ & $\begin{array}{l}\text { Bound of } 2 \text { aliphatic } \mathrm{C} \text { with branched double bound and } 2 \text { non } \mathrm{C} \text { atoms with } \\
0 \text { further connections }\end{array}$ \\
\hline$[C]=[C]([C])[! C]$ & $\begin{array}{l}\text { Bound of } 3 \text { aliphatic } \mathrm{C} \text { and one non } \mathrm{C} \text { atom, with branched double bound } \\
\text { between first and second } \mathrm{C}\end{array}$ \\
\hline$[C]=[C]([C])[C]$ & $\begin{array}{l}\text { Bound of } 4 \text { aliphatic C, with branched double bound between second and } \\
\text { third C }\end{array}$ \\
\hline$[C]=[C]=[C]$ & 3 aliphatic $\mathrm{C}$ with double bounds \\
\hline$[! C X 1][C] \#[C]$ & $\begin{array}{l}\text { Bound of aliphatic } \mathrm{C} \text { with triple bound to aliphatic } \mathrm{C} \text { and } \mathrm{C} \text { with } \mathrm{O} \text { further } \\
\text { total connections }\end{array}$ \\
\hline$[! X 1][C] \#[C]$ & $\begin{array}{l}\text { Bound of aliphatic } C \text { with triple bound to aliphatic } C \text { and one atom with } 0 \\
\text { further connections }\end{array}$ \\
\hline$[! \# 1][\mathrm{CH} 2][! \# 1]$ & $\begin{array}{l}\text { Bound of aliphatic } \mathrm{C} \text { with two further hydrogen and two atoms that are not } \\
\text { hydrogen atoms }\end{array}$ \\
\hline$[\mathrm{CX} 3 \mathrm{H} 1]=[\mathrm{CX} 3 \mathrm{HO}]$ & $\begin{array}{l}\text { Bound of aliphatic } \mathrm{C} \text { with } 1 \text { further total connection with } 1 \text { further hydrogen } \\
\text { and aliphatic } \mathrm{C} \text { with } 2 \text { further total connections with } 0 \text { further hydrogen }\end{array}$ \\
\hline$[\mathrm{CX} 3 \mathrm{HO}]=[\mathrm{CX} 3 \mathrm{HO}]$ & $\begin{array}{l}\text { Bound of two aliphatic } \mathrm{C} \text { with } 2 \text { further total connections with } 0 \text { further } \\
\text { hydrogen }\end{array}$ \\
\hline$[\mathrm{CX} 3 \mathrm{H} 2]=[\mathrm{CX} 3 \mathrm{H} 1]$ & $\begin{array}{l}\text { Bound of aliphatic } C \text { with } 0 \text { further total connections with } 2 \text { further } \\
\text { hydrogen with aliphatic } C \text { with } 1 \text { further total connection with } 1 \text { further } \\
\text { hydrogen }\end{array}$ \\
\hline$[\mathrm{CX} 3 \mathrm{H} 1]=[\mathrm{CX} 3 \mathrm{H} 1]$ & Bound of two aliphatic $\mathrm{C}$ with 1 further total connection with 1 hydrogen \\
\hline$[\mathrm{CX} 3 \mathrm{H} 2]=[\mathrm{CX} 3 \mathrm{HO}]$ & $\begin{array}{l}\text { Bound of aliphatic } C \text { with } 0 \text { further total connections with } 2 \text { further } \\
\text { hydrogen with aliphatic } C \text { with } 2 \text { further total connections with } 0 \text { further } \\
\text { hydrogen }\end{array}$ \\
\hline$[\mathrm{c}][\mathrm{CX} 4 \mathrm{H} 3]$ & $\begin{array}{l}\text { Bound of aromatic } \mathrm{C} \text { with aliphatic } \mathrm{C} \text { with } 0 \text { further total connections with } \\
3 \text { further hydrogen }\end{array}$ \\
\hline$[c][\mathrm{CX} 4 \mathrm{H} 2]$ & $\begin{array}{l}\text { Bound of aromatic } \mathrm{C} \text { with aliphatic } \mathrm{C} \text { with } 1 \text { further total connection with } 2 \\
\text { further hydrogen }\end{array}$ \\
\hline$[\mathrm{c}][\mathrm{CX} 4 \mathrm{H} 1]$ & $\begin{array}{l}\text { Bound of aromatic } \mathrm{C} \text { with aliphatic } \mathrm{C} \text { with } 2 \text { further total connections with } \\
1 \text { further hydrogen }\end{array}$ \\
\hline$[\mathrm{CX} 2 \mathrm{H} 1] \#[\mathrm{CX} 2 \mathrm{HO}]$ & $\begin{array}{l}\text { Triple bound of aliphatic } C \text { with } 0 \text { further total connections with } 1 \text { further } \\
\text { hydrogen and aliphatic } C \text { with } 1 \text { further total connection with } 0 \text { further } \\
\text { hydrogen }\end{array}$ \\
\hline$[\mathrm{CX} 2 \mathrm{HO}] \#[\mathrm{CX} 2 \mathrm{HO}]$ & $\begin{array}{l}\text { Aliphatic } \mathrm{C} \text { with triple bond and } 1 \text { further total connection } 0 \text { further } \\
\text { hydrogen }\end{array}$ \\
\hline [R] & Number of atoms in ring \\
\hline
\end{tabular}


Table S6 Tables of utilized parameters for hyperparameter optimization

\begin{tabular}{|c|c|}
\hline Parameter & Optimization range \\
\hline (Neurons per Layer) & $\begin{array}{l}\left(\text { num }_{\text {feat }}\right), \quad\left(\text { num }_{\text {feat }}, \text { num }_{\text {feat }}\right), \quad\left(\text { num }_{\text {feat }}, \text { num }_{\text {feat }},\right. \\
\left.\text { num }_{\text {feat }}\right), \quad\left(2^{*} \text { num }_{\text {feat }}\right), \quad\left(2^{*} \text { num feat }_{\text {feat }}, 2 * \text { num }_{\text {feat }}\right), \\
\left(2^{*} \text { num }_{\text {feat }}, 2^{*} \text { num }_{\text {feat }}, 2^{*} \text { num }_{\text {feat }}\right),\end{array}$ \\
\hline Droprate & $0.001,0.01,0.05,0.1,0.2,0.3,0.4,0.5$ \\
\hline Learning rate & $1 e-4,1 e-3,1 e-2$ \\
\hline Learning weight decay & $0,1 e-8,1 e-6,1 e-4,1 e-2$ \\
\hline Number of training epochs & $500,1000,1500,2000$ \\
\hline Activation function & ReLU, ELU, Sigmoid \\
\hline$X$ feature scaler & None, MinMaxScaler, RobustScaler \\
\hline y feature scaler & None, MinMaxScaler, RobustScaler \\
\hline
\end{tabular}

Utilized Scalers:

\begin{tabular}{|l|l|l|}
\hline MinMaxScaler $=\frac{x_{i}-\bar{x}_{i}}{x_{i, \max }-x_{i, \min }}$ & \\
\hline RobustScaler $=\frac{x_{i}-Q_{50}\left(x_{i}\right)}{Q_{75}\left(x_{i}\right)-Q_{25}\left(x_{i}\right)}$ & \\
\hline
\end{tabular}


Figure S7 Testing results of cross-validation for pure compounds prediction

Density
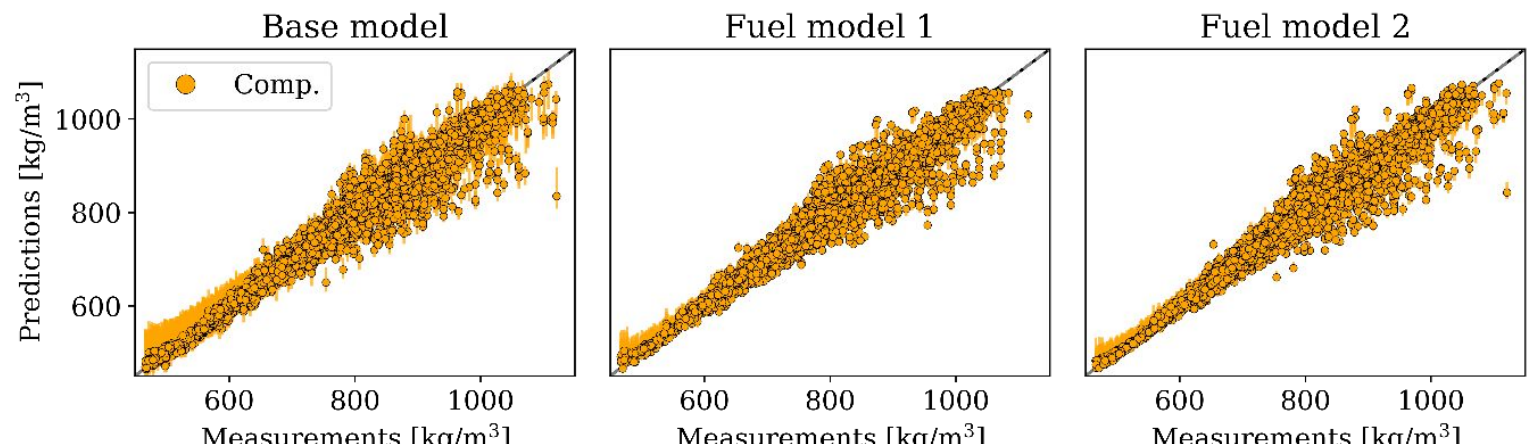

\begin{tabular}{|l|c|}
\hline MAE & 8.45 \\
\hline PICP & 81.57 \\
\hline NMPIW & 5373.65 \\
\hline MAOE & 11.32 \\
\hline
\end{tabular}
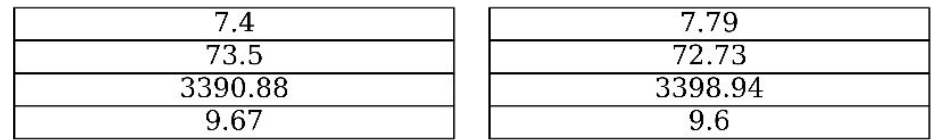

\section{Freezing point}
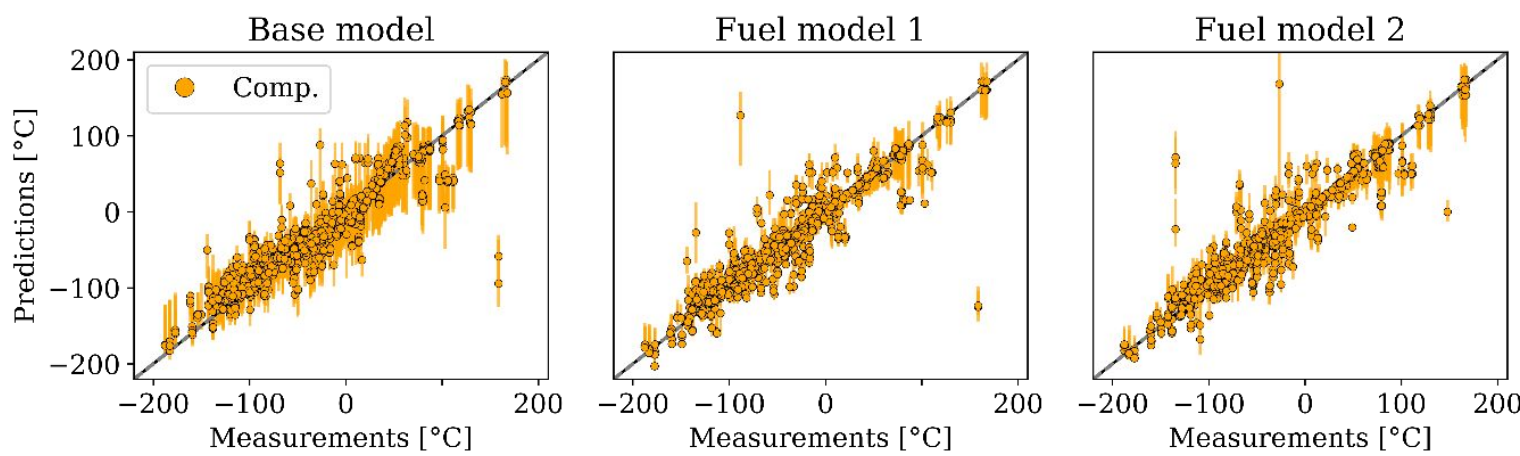

\begin{tabular}{|l|c|}
\hline MAE & 16.32 \\
\hline PICP & 78.04 \\
\hline NMPIW & 6645.98 \\
\hline MAOE & 16.89 \\
\hline
\end{tabular}
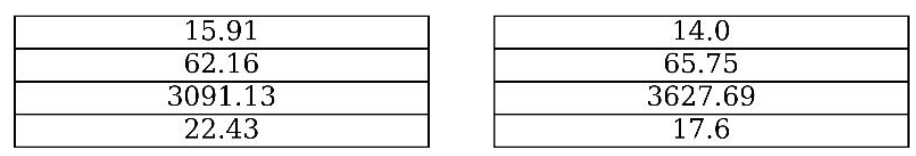

Flash point
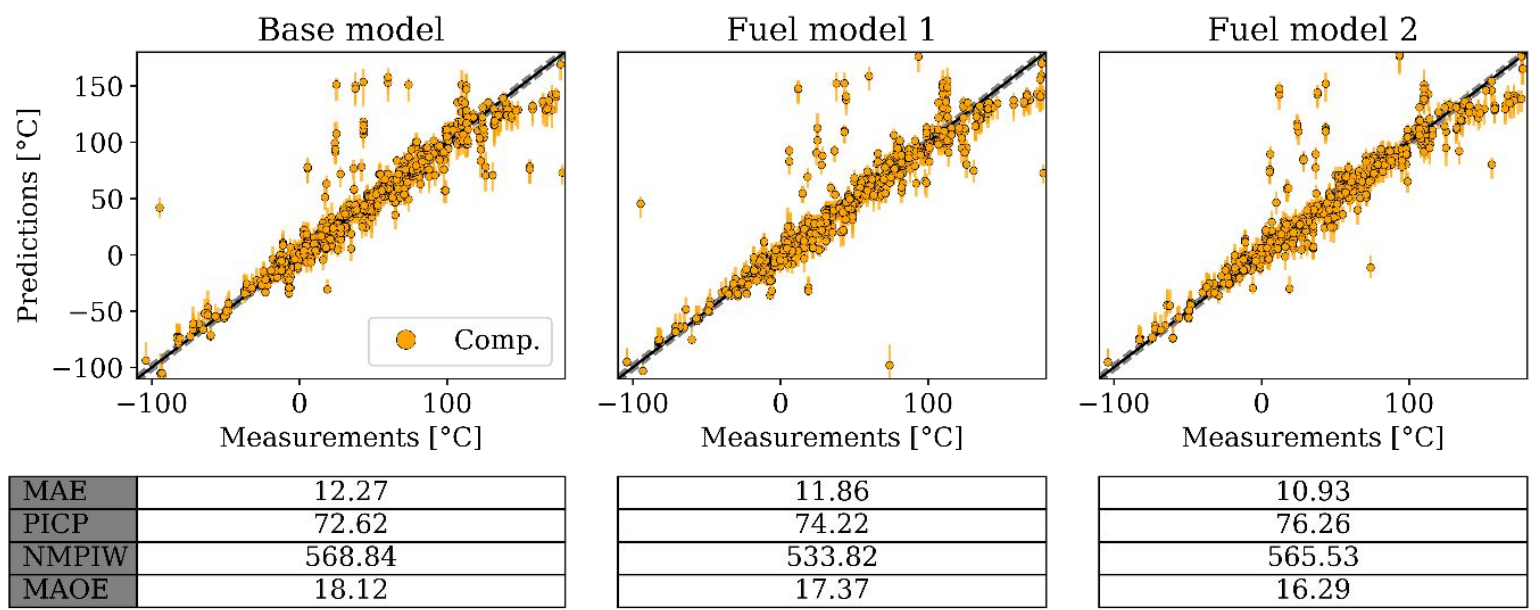

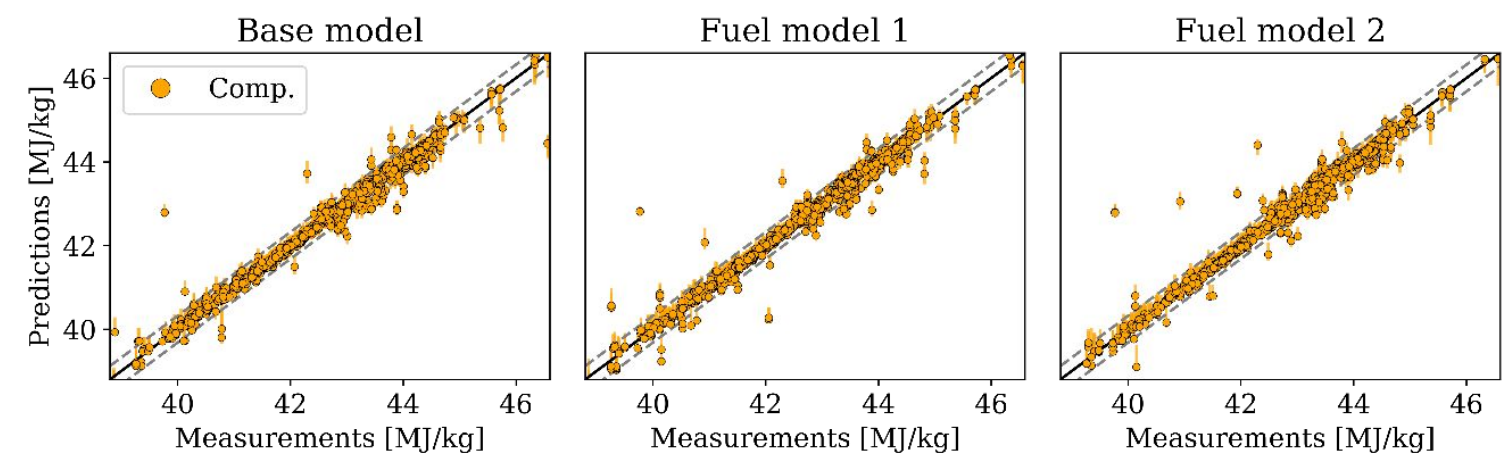

\begin{tabular}{|l|c|}
\hline MAE & 0.08 \\
\hline PICP & 98.67 \\
\hline NMPIW & 101.32 \\
\hline MAOE & 0.19 \\
\hline
\end{tabular}

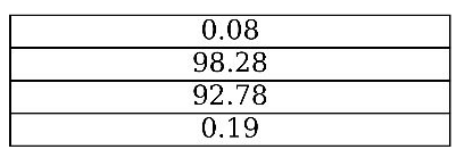

\begin{tabular}{|c|}
\hline 0.08 \\
\hline 98.12 \\
\hline 102.61 \\
\hline 0.23 \\
\hline
\end{tabular}

\section{Surface tension}

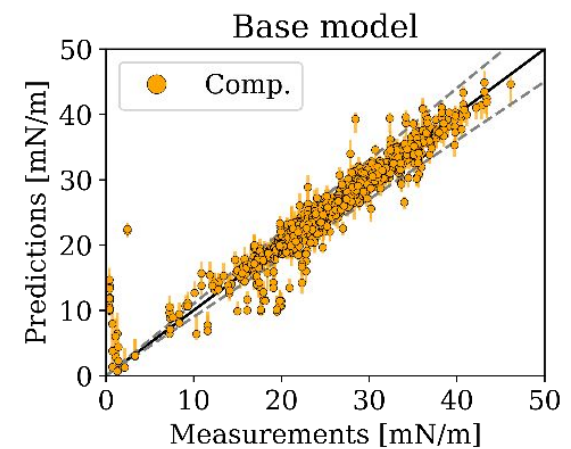

Fuel model 1

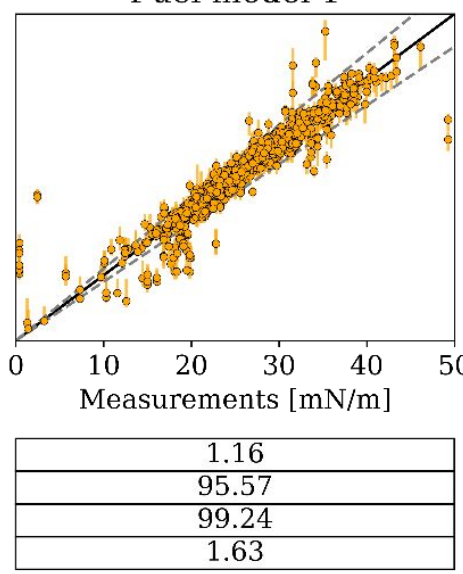

Fuel model 2

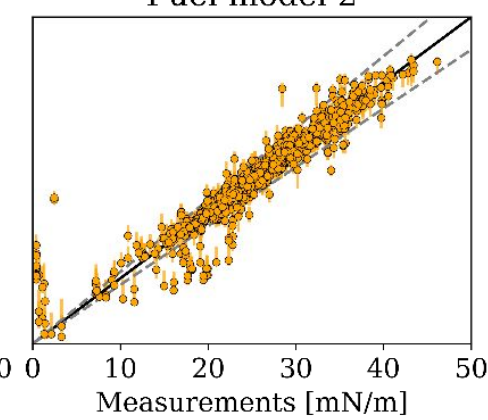

\begin{tabular}{|l|c|}
\hline MAE & 1.29 \\
\hline PICP & 94.19 \\
\hline NMPIW & 113.93 \\
\hline MAOE & 2.24 \\
\hline
\end{tabular}

\begin{tabular}{|c|}
\hline 1.33 \\
\hline 94.06 \\
\hline 110.63 \\
\hline 2.14 \\
\hline
\end{tabular}

\section{Kinematic viscosity}
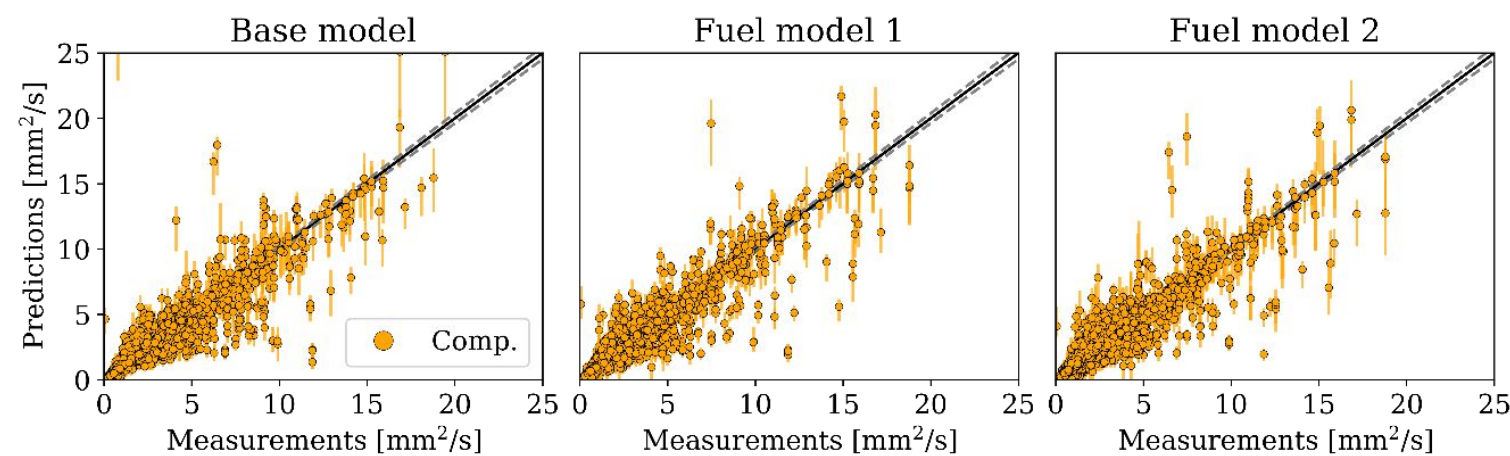

\begin{tabular}{|l|c|}
\hline MAE & 0.37 \\
\hline PICP & 87.21 \\
\hline NMPIW & 3867.19 \\
\hline MAOE & 1.05 \\
\hline
\end{tabular}

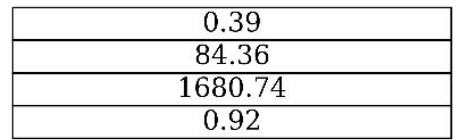

\begin{tabular}{|c|}
\hline 0.42 \\
\hline 86.27 \\
\hline 5562.31 \\
\hline 1.02 \\
\hline
\end{tabular}

